\title{
Conceptions of Brazilian Undergraduates About the Environment and Environmental Education ${ }^{*}$
}

\author{
Sônia Maria Marchiorato Carneiro, Tania Stoltz \\ Universidade Federal do Paraná, Curitiba, Brazil \\ Carla Luciane Blum Vestena \\ Universidade Estadual do Centro-Oeste, Guarapuava, Brazil \\ Valdir Nogueira \\ Universidade Federal de Santa Maria, Santa Maria, Brazil \\ Thiciane Pieczarka \\ Universidade Federal do Paraná, Curitiba, Brazil \\ Roberta Rafaela Sotero Costa \\ Universidade Federal Tecnológica do Paraná, Irati, Brazil \\ Marlene Schüssler D’Aroz, Fernanda Hellen Ribeiro Piske \\ Universidade Federal do Paraná, Curitiba, Brazil
}

\begin{abstract}
The purpose of this study is to assess what final year Geography undergraduates from Brazil at two public and one private universities think about the environment and environmental education, using Piaget as an epistemological basis, given his interactionist and constructivist perspective in understanding cognitive development. Analysis was made of the conceptions of 30 final year Geography course graduation students at two public and one private universities. The results show that the concepts of the students analysed regarding the environment and environmental education are related to the second and the beginning of the third level of conceptual understanding. The view that half of the students analysed have about the environment is from a perspective relating society to nature, whereas the remainder have a generic and fragmented view. That is to say, those who showed the second level of understanding made references to the environment which sometimes considered nature and sometimes considered people, but with one excluding the other; the ability to describe is evoked from facts associated through their shared meaning. On the other hand, those who showed themselves to be at the beginning of the third level of understanding exhibited integration of different sets of information within a cognitive and affective system, conflicts were taken into account in their explanation of reality, and reality was considered regardless of their wishes and as being in a continuous process of transformation. A similar fact occurred regarding environmental
\end{abstract}

\footnotetext{
* This paper was presented in The 43rd Annual Meeting of the Jean Piaget Society, Chicago, USA, 2013.

Sônia Maria Marchiorato Carneiro, Ph.D., senior lecturer, Postgraduate Education Programme, Universidade Federal do Paraná.

Tania Stoltz, Ph.D., lecturer, Postgraduate Education Programme, Universidade Federal do Paraná.

Carla Luciane Blum Vestena, Ph.D., lecturer, Postgraduate Education Programme, Universidade Estadual do Centro-Oeste.

Valdir Nogueira, Ph.D., lecturer, Department of Teaching Methodology, Universidade Federal de Santa Maria.

Thiciane Pieczarka, M.Ed., Ph.D. candidate, Postgraduate Education Programme, Universidade Federal do Paraná.

Roberta Rafaela Sotero Costa, M.Ed., lecturer, Department of Arts, Universidade Federal Tecnológica do Paraná.

Marlene Schüssler D’Aroz, Ph.D., lecturer, Technology Incubator for Popular Cooperatives, Universidade Federal do Paraná.

Fernanda Hellen Ribeiro Piske, M.Ed., Ph.D. candidate, Postgraduate Education Programme, Universidade Federal do Paraná.
} 
education. The majority of the students related their concepts to the development of environmental awareness-raising (i.e., the beginning of the third level of understanding) and the remainder of the students as the transmission of information and norms (i.e., the second level of understanding). The conclusion is reached that with regard to the training of Geography undergraduates and also with regard to environmental education, a curricular perspective is needed that places value on interdisciplinarity and educational practice as a problematization of geographical spatiality in socio-environmental interrelations.

Keywords: Geography, environmental education, construction concepts, Piaget

\section{Introduction}

The environment is a global fact that can no longer be ignored in the contemporary world since it affects quality of life on our planet. Despite environmental warnings given since the 1960s, the proposal of sustainable development — especially following the Rio-92 Summit—has shown itself to still be ambiguous with regard to justice to reduce social inequalities and, within this context, overcome socio-environmental problems within and between countries. Hence, the urgency of "(...) building productive rationality based on sustainability and social equity” is underscored (Leff, 2001, p. 60).

In Brazil, Federal Law 9795/99 (Federative Rupublic of Brazil, 1999), as regulated by Decree 4281/2002 (Federative Rupublic of Brazil, 2002), establishes the National Policy on Environmental Education. Articles 8 and 11 of the law provide that all graduate, postgraduate, and refresher courses must incorporate the environment in their curricula and programmes. Various studies have been conducted in order to evaluate undergraduate and postgraduate students' understanding of the environment, as well as that of elementary education teachers (Campos, 2000; Tozoni-Reis, 2002; Bretones \& Compiani, 2011; Lima \& Oliveira, 2011; Guimarães \& Inforsato, 2012; among others). However, research with this focus can be seen to be absent with regard to Geography courses.

The purpose of this study is to assess what final year Geography undergraduates at two public and one private universities think about the environment and environmental education, using Piaget as an epistemological basis, given his interactionist and constructivist perspective in understanding cognitive development.

According to Piaget and Inhelder (2003), the origin of knowledge is in action and not just in perception nor even in an a priori subject. According to Smith (2012), Piaget researched the epistemology of development focusing on two phenomena: (a) the creation of the new; and (b) the formation of necessary knowledge. Stoltz, Costa, Pieczarka, Othman, Cooper, and D’Aroz (2014) pointed out that through interaction between the subject and the environment, intelligence develops simultaneously with the cognitive construction of reality. Knowledge does not involve an absolute beginning, but rather gradual growth in learning real facts about the environment under the inflow of social and subjective norms, whether they be structural or relating to the workings of affective and cognitive schemas (Piske \& Stoltz, 2012).

\section{Geography and Environmental Education}

The environment is one of the focus areas dealt with academically by Geography worldwide (Cordero \& Svarzman, 2007); and in relation to the Brazilian elementary education school curriculum, there is a legal recommendation to address the environment in a cross-cutting manner, valuing the environmental dimension in 
each curricular discipline (Federative Rupublic of Brazil, 2002). This methodological approach is based on some of the underlying principals of environmental education: the environment as a whole and the interdependence between the natural and social milieu; the link between ethics, education, work, and social practices; and the interdisciplinary perspective (Federative Rupublic of Brazil, 1999).

Geography contributes to environmental education to the extent that it enables students to reflect about social interrelations and the relations of these with the natural environment on diverse geographic scales. The fundamental presupposition, in this direction, is the treatment of geographical knowledge based on a new understanding of mankind and the world in the face of the socio-environmental crisis, overcoming a dichotomous vision of society and nature, given that “(...) Nature and humans, as well as society and the environment, establish a relationship of mutuality and co-belonging, forming a single world” (Carvalho, 2004, p. 36).

In this sense, the environment (ceases to be) is no longer visualized as a synonym of a natural milieu, and becomes established as a space of complex interactions between society, culture, and the biophysical basis of vital processes. Interpreting spatial complexity regarding socio-environmental issues, therefore, implies the contextual understanding of natural, cultural, legal, political, technological, social, and economic multiple dimensions, and the mutual interferences on local and global scales (Castellar, 2005; Camargo, 2005; Reigota, 1995).

As a consequence, when educators build specific knowledge from an interdisciplinary perspective, clear explanations of geographical spaces have to be sought with emphasis on unity and diversity, the impacts of conflicts and tensions on milieu, as well as causal interrelational processes in organizational changes and alterations.

Thus, when apprehending and analysing sociocultural and economic similarities and, on the other hand, the self-identities of the same dimensions in different places and regions, it is fundamental to bear in mind the problems affecting living conditions in the different geographical spaces, including their interdependences in material and cultural terms and in terms of production and consumption, always with a greater or lesser degree of risk of local, regional, or global degradation. From this perspective, it is important to reflect on actions of socio-environmental sustainability, taking into account the limits and potentials of each geographic space, with regard to natural assets (adequate use and reuse) and sociocultural assets (knowledge, local living practices, creativity, services, etc.).

Geographical education, by revealing the complex spatial relations between society and nature, will be corroborating a politicized environmental education (Sansolo \& Cavalheiro, 2001/2003) characterized by a civic conception referenced in socio-environmental values: ethically responsible attitudes and conducts regarding protection, prevention, and problem-solving from a quality of life viewpoint. Spatial and civic consciousness, in this connection, comprises clarification of rights and duties in the political and juridical actions of subjects in society, both locally and globally (Nogueira, 2009). In reality, citizens' commitment to their community, as their own place, concerns the quest for improving and transforming living conditions. As such, the mediation of education is needed in building and sustaining respect for social diversity and biodiversity, being disposed to solidarity, cooperation, honesty, and commitment to equitable justice and, moreover, prudence in decisions and actions in the face of risks of irreversible socio-environmental harm (Gadotti, 2000). 


\section{The Construction of Concepts}

With effect from the 1970s, owing to the signification of cognitive processes in educational practice, Brazilian university degree courses have sought to base themselves on Piagetian interactionist and constructivist theory. Training teachers for elementary education, through Geography degree courses, can be benefitted by this conception if it is used to guide practices in schools in terms of geographical education interacting with environmental education. For this reason, it is important for educators to have an understanding of the cognitive, social, and affective processes of constructing knowledge and attitudes in order to contribute to the development of critical reflection on socio-environmental issues, especially with regard to the construction of epistemically significant concepts.

According to Piaget (1974a; 1974b; 1975; 1981; 1983; 1987), the construction of concepts occurs through the interaction between subject and objects that the environment enables them to experience and know. In the process of understanding experiences, conceptual schemas are different from practical schemas, that is to say, conceptual schemas result from a mental action or reflection, whilst practical schemas result from the very exercising of the practical action; but both are built through that, which is generalized from the subject's action (Stoltz et al., 2014).

The process of constructing concepts involves attributing significations, based on what the subject can do with the object and on what actions result in. Significations are, therefore, part of the genesis of building concepts and depend on the subject's interaction with specific objects of knowledge. Therefore, as a learner interacts with the multiple dimensions of the environment, he/she builds affective and cognitive significations and, as part of this process, grasps consciousness of the environment in its totality.

The first significations are sensorimotor ones and involve a kind of practical intelligence which defines itself as it is used, whereby there is a limited understanding of reality described in static terms. Taking Delval (2002) as a reference, at the first conceptual level, subjects have not yet learnt the interrelational dynamics of biophysical, social, and personal reality. This implies not perceiving the contradictions and conflicts in a given reality. Interpretation of the world is naive, uncritical, and syncretic; concepts are centred on personal wishes and needs. Although this cognitive process is peculiar to children in their first stage of development, concepts on this level can be found in adults when they enter a new field of knowledge. It can be noted that at this level of understanding, descriptions express concrete exemplifications of the environment in which the subject lives.

Stoltz et al. (2014) and Piske and Stoltz (2012) explained that the evolution of the ability to understand depends on the development of intelligence and, in Piaget, this is related to the factors of organic maturation, interaction with physical objects, social interaction and transmission, and the self-regulating process of equilibration. At the second level of understanding, the subject begins to have an insight into the dynanism of reality, based on its contradictions and conflicts, but it is not yet integrated in an explanatory system. Social roles and relations also begin to be understood, beyond the subject's own personal relations and needs.

At the third level of understanding, different sets of information are integrated in a cognitive and affective system internalized by the subject. Conflicts are not only perceived but also taken into consideration in the explanation of reality. The subject increasingly considers a reality that exists regardless of their wishes, in a dynamic manner and in a continuous process of transformation. Significations here are more 
comprehensive and the subject seeks coherence in integrating their different experiences with the objective world.

Thus, the movement of conceptual construction initially takes schemas constructed by the subject, when interpreting a new concept, constituting a movement of integrative assimilation of data obtained from reality. In this process, constructing a new concept demands the occurrence of a cognitive conflict which takes place in the subject when the new concept is interrelated with the knowledge the subject already has (knowledge built throughout the subject's history); since when the subject realizes that there is a difference between the knowledge they have and do not have about an object, this leads to conflict. Conflict can lead to accommodation, whereby the subject adjusts to the object and changes his/her conceptual schemas. The temporary equilibrium between assimilation and accommodation results in adaptation, so that new conceptual schemas, in turn, will serve as the basis for new adaptations.

Teachers need to work on the concepts students present, not remaining restricted to them, but to enable them to reflect and build more elaborate knowledge. When teachers provoke students with knowledge, this may contribute to a cognitive conflict being produced, thus, making the new knowledge meaningful to the students. Values are built during this process, constituting references for the subject's actions. The value development process is integrated with cognitive development and depends on the subject's grasp of consciousness regarding his/her actions in relation to socio-environmental reality. Teachers, therefore, need to enable students to reflect on their practices regarding the environment in which they live, provoking them to think about the relation between means and ends in the analysis of socio-environmental issues. Emphasis will be on the process of transforming learning and understanding the relations between society and nature, with the aim of reviewing values and practices. In this process of reflexive cognition, students will be able to position themselves based on values with regard to environmental issues. Consequently, educators need to provide guidance that is questioning and which motivates students to think and act in terms of building values and attitudes relating to civic consciousness, such as participative and joint responsibility for the sustainable management of their life contexts.

\section{Method}

This qualitative exploratory study involving analysis and interpretation of what the subjects said (Lüdke \& André, 1986) began by setting the criteria for the choice of the universities: having a Geography graduation course, and being accessible or available for the study and being located in the southern region of Brazil in cities in which the researchers lived. Based on these criteria, three universities in southern Brazil were selected using convenience sampling: U1 (a state-level institution, in the state of Paraná), U2 (a federal-level institution, in the state of Paraná), and U3 (a private institution, in the state of Santa Catarina).

Ten final year undergraduates from each of the institutions selected were later chosen randomly by drawing lots. As it was a qualitative study, the sample did not seek to achieve a statistically representative number of people, but rather followed the indications of Delval (2002) that “(...) 10 subjects is an adequate number (...). It is hard to reach conclusions with a smaller number of subjects (...)” (p. 101), whereas with a large number analysis is more arduous and complex, because the subjects' replies usually express very well the way they think and generally reflect how their mind is organized and their view of the world. The choice of the number of subjects also took into account the following rule: “(...) When more subjects are added but new kinds of replies do not appear, we can consider that we have a sufficient number (...)”, given that in general, 
“(...) The replies are of the same nature and new information is not obtained (...)” (Delval, 2002, p. 102), which is relevant for an empirical study. During contacting with each university's Geography course coordinator, time was arranged to hold the interviews, after each respondent having given his/her informed consent. The interviews were conducted with 30 Geography undergraduates from two public universities in the state of Paraná (10 from each one) and from a private university in the state of Santa Catarina (also 10 subjects).

Semi-structured interviews inspired by Piaget’s clinical method were conducted (Piaget, 1926; Delval, 2002). The interviews were conducted around the following two questions:

1. What comes to mind when you think about the environment? Explain.

2. Today, the socio-environmental problems in our reality are visible. Strategies are needed not only to minimize but also to solve these problems. One of the basic strategies is environmental education. What does environmental education mean to you? Explain.

The questions posed to the respondents enable the elucidation of concept construction to the extent that they make it possible "to speak freely and discover spontaneous trends, rather than channelling and restricting them” (Piaget, 1926, p. 7). The interviews were recorded and later transcribed. Data analysis was performed based on categories generated by the contents of each subject's answers and those of the subjects as a whole, with interpretation being based on the theoretical reference. The examples of replies given in the analysis have been kept anonymous with regard to the identification of the subjects and institutions.

\section{Data Analysis and Discussion}

The analysis of the interview replies enabled the identification of partial concepts about the environment and environmental education in accordance with current theoretical references in the three institutions studied. In order to explain the results, focused categories were identified as follows in the examples and respective analyses below, in relation to all the study subjects.

1. Two types of focus occurred with regard to the environment, one more relational and the other more generic and fragmentary:

(a) Relational view of society and nature (16 respondents, 53.5\%):

Environment is the integration or interaction of nature, human beings which (are) also nature (...) human beings depend, society depends on nature, regardless of whether it's an urban environment or a rural one. (U2 undergraduate).

(...) Environment is the relationship (...) between all microorganisms, animals, vegetables, mankind, and all living beings in the milieu in which they live, relate with each other (...). It is a very large interrelationship (...), because they are closely connected systems, one thing's linked to another (...), like a spider's web (...), mankind adapts itself to this milieu (...). It is both an active agent because it transforms this milieu (...) interrelates (...) and also a passive agent, because it suffers interference from other milieux and from other people doing other activities. (U3 undergraduate)

(b) Generic and fragmentary view (14 subjects, 46.5\%), exemplifications of this category:

(...) Right from my house, my garden, my work (...) the entire planet, including us (...) mere human beings, animals, plants, creatures... (U2 undergraduate).

Environment is the biological, chemical, and physical conditions for the existence of life (...) all living beings (...) plants, animals, including man (...) these elements, the earth, the air, physical phenomena... (U1 undergraduate)

2. With regard to environmental education, two areas of understanding appeared, one relating to the development of environmental awareness (60\%), comprised of three levels of understanding; and the other relating to knowledge transmission (40\%) from two perspectives. 
The first area of understanding relates to the process of environmental grasping of consciousness:

(a) Generic and stereotyped view of nine subjects (30\%), the following is an example of this category:

(...) Environmental education should be a subject at school (...). I think there needs to be a collective consciousness (...) install environmental awareness. (U2 undergraduate)

(b) The sustainable relation between mankind, society, and nature (six subjects, 20\%):

(...) Environmental education (...) does not mean (...) our (...) looking after a plant (...) a bird (...). Environmental education is much more comprehensive (...). It deals with the human being (...) both at the individual level and also at the collective level, as a community (...). It deals with values, cultural issues (...), environmental education that can be said to be (...) in harmony, in equilibrium with the environment. In equilibrium, respecting (...) human rights and even (...) protecting environmental rights (...), the sustainment of the human being as a form of environmental sustainment. (U3 undergraduate)

(c) Change of habits, in the view of three subjects (10\%):

(...) Raising awareness (...) what can be thrown away or what cannot, what needs to be kept, what needs to be preserved or even saved, even knowing how to use something (...) or not wasting something you could use for longer, that is a way of saving (...). Today, there is unbridled consumerism and everything is disposable. (U1 undergraduate)

The second area of understanding relates to knowledge transmission:

(a) Information, knowledge, and enlightenment (six subjects, 20\%):

Environmental education is providing knowledge (...), the importance of the natural environment (...), the importance of the relation between the environment and a person's daily actions (...), providing knowledge... (U2 undergraduate)

(b) Norms for actions in the environment (six subjects, 20\%):

Environmental education would be a means of showing ways of preserving and raising students' awareness in special disciplines within elementary education. (U3 undergraduate)

The results reveal that the understanding of the environment, according to the examples of the replies, was characterized by its approaching desirable criteria, to the extent that the subjects visualized environment in connection with relations between society and nature, especially in the case of the more relational category sub-group (53.5\%); although it can be seen that this group is in distributional equivalence with the more generic and fragmentary category sub-group (46.5\%), which in turn showed only signs of relational perceptions. In this relational understanding of the environment by the study subjects, a view can be seen which includes human beings as part of nature, i.e., being part of the Web of relations of natural, social, and cultural life. This perspective is fundamental to the understanding of the interdependencies of sustaining life and prudent actions propitious to the dynamic equilibrium of ambient reality. In this sense, the words of Ana Maria Freire are worthy of note:

Without (nature), we are without ourselves. We are extremely alone, both in the world that has been given to us, and also in the world we have built, because, in truth, both of them, dialectically speaking, form the world in which being human makes sense. (Freire, 2007, p. 14)

Despite the detection of an opening for the relational conception of environment, the interpretation the study subjects make of socio-environmental dynamics (local and global multiple dimensions) in relation to the different geographical spaces is still simplistic—showing difficulties in explaining relations between the 
various dimensions of ambient reality, i.e., their pronouncements denote a stereotyped influence of shared ideas current in the institutional culture, both in university milieux and also at school in general-in this case, especially via teaching materials (Ribeiro, 2006). This relational culture of reality, in turn, arises from very recent elaboration, and given the complexity proper to socio-environmental issues, does not manage to be learnt and worked on in accordance with satisfactory criteria by teachers and teacher trainers (Silva, 2007). Moreover, the discipline-based curriculum structure-which fragments knowledge and is distant from an interdisciplinary perspective-hampers comprehensive and integrated apprehension of geographical space, in its various scales, from the perspective of the environment and its problems, in all its ecological, historical, economic, political, cultural, and ethical complexity (Grün, 1996; Loureiro, 2006).

With regard to conceptions of environmental education, $60 \%$ of the subjects demonstrate awareness of the environment from two points of view: (a) a more up-to-date view (30\%), closer to the perspective of sustainability, in terms of the mankind-nature relationship; and (b) a more general and stereotyped view (30\%), of a more mechanical-memorized kind. The conceptions expressed by the remaining subjects (40\%) followed traditional educational practices, i.e., the transmission and reproduction of information and norms, above all with regard to the natural environment and its conservation. The overall outcome of these results, in relation to the contents of the subjects' pronouncements as to the conception of environmental education, shows a vision that is still incipient in terms of progress that is both desirable and certainly possible towards reference criteria for training Geography teachers. With the exception of the subjects who expressed a relation between environmental education and sustainable attitudes and habits—a fundamental presupposition in this area of education in view of the quality of life on the planet-the majority understood it in a broad perspective, i.e., without an understanding focused on the very purpose of environmental education, which is the formation of socio-environmentally-based civic consciousness. Within this context, an individualist bias in the training of the future educators involved in the study was found with regard to confronting socio-environmental problems, whereby these are disconnected from their historical, social, and cultural contexts. Hence, the absence of a spatial and civil consciousness based on referential values and, therefore, politicized and ethically responsible in decisions and actions regarding quality of life, in the face of the conditions of each geographical space, its possibilities and limits (Damiani, 2001; Freire, 2005; Vesentini, 2005; Nogueira, 2009).

Based on this analysis, greater conceptual elaboration can be perceived in relation to the environment than in relation to environmental education, probably because of the greater intensity with which environmental issues circulate, including in the media. In the case of environmental education, the subjects' replies were more random, showing that this dimension of the educational process is still at an initial phase in teacher training -as a result of an inadequate education policy as to the effective inclusion of this educational dimension in academic curricula and, consequently, the lack of preparation of teaching professionals (Santos \& Sato, 2001/2003).

Based on Delval (2002) and Piaget (1926), the examples of what the research subjects say express that most of them present conceptions of environment and environmental education that relate to the second and the beginning of the third level of conceptual understanding. With regard to the second level, considerations about invisible aspects of situations experienced can be observed in the subjects' representations-processes are not perceived directly but rather inferred by the information, for example, within this study, references appear to the environment which at times consider nature and at others consider humans, where one excludes the other, 
rather than interacting, this being more intuitional than relational analysis. The ability to describe is an evocation of facts associated by their common meaning, but the explanation of what occurs and the possibilities of change are still not very explicit and are by inkling.

Still with regard to the second level of understanding, the subjects can be perceived as having insight as to the dynamism of reality, including its contradictions and conflicts, but it is not yet integrated in an explanatory system. Social roles and relations also begin to be understood, beyond the subject's own personal relations and needs. With regard to the third level of understanding of environment and environmental education, the beginning of the coordination and integration of knowledge can be seen and this progress can be identified in their speech. This certainly enables them to make incipient criticisms and indicate some alternative solutions for environmental problems. At this third level of understanding, different pieces of information are integrated into a cognitive and affective system internalized by the subject. Conflicts are not only perceived, but are also taken into consideration in the explanation of reality. The subject increasingly considers a reality that exists regardless of their wishes, in a dynamic manner and a continuous process of transformation. Significations here are more comprehensive and the subjects seek coherence when integrating their various experiences with the objective world, given that “(...) The subjects' actions and operations encompass reality in a network of possibilities and necessary relations (...), so that each new happening updates other possibilities in a system of logical and mathematical transformation which justifies them (...)” (Piaget, 1981, p. 134).

The fact that the research subjects already have information about this theme does not qualify them to have a better spontaneous understanding of environmental issues and their relation with the educational process, given that for this to occur, a reflective process of cognitive construction is necessary, in which pre-existing ideas are activated in the sense of progressing from initial learning and understanding to new more systematized and integrating significations. Therefore, the first interpretations of new data involve concepts the subject already has. Once, it is perceived that there is conflict between what the subject knows and what is presented by the new information, a different level of understanding becomes possible, resulting from reflection about previous and current knowledge.

\section{Final Considerations}

Although the subjects of the study were in the final year of a Geography degree course, their understandings of the environment and environmental education are more directed towards the relation between aspects and facts and less towards knowledge of the underlying determinants explaining the facts, and are related to the dynamic movement of knowledge transformation and critical understanding of reality based on references. This situation indicates the significant differences between receiving information and integrating it into a system of knowledge. Teacher training, as part of the Geography degree course, should be more concerned about the need for this integration, encouraging reflection about the process of knowledge construction, beyond isolated and non-contextualized aspects, facts, and contents.

The study's diagnostic validity, focusing on understandings of the environment and environmental education, is therefore sustained as evidence of the need for a epistemological and methodological reorientation and, as such, the need to restructure the teacher training curriculum - in the case in question in the area of geography education. To this end, the need exists to progress from a generalized and fragmentary view of the environment towards an understanding of the complex totality of geographic space-and, in this sense, of the environment, in different contexts of space and time. 
Based on the presupposition of a referenced understanding of environment, it will be possible to rebuild with the educators a conception of environmental education which surpasses the generic, stereotyped, and reiterative biases present in the universe studied. In this regard, Carvalho (2004) cautioned that "The expression environmental education has come to be used as a generic term (...). Based on what conception of environment are certain social practices being classified (...) as adequate or inadequate?” (p. 153).

Teacher trainers, especially in relation to elementary education, will need to have their references in a new understanding of world and mankind and, to this end, build values and critical attitudes aimed at practicing a culture of socio-environmental sustainability—as opposed to an instrumental, predatory, and unfair rationality which maintains unsustainable conditions, for both present and future generations. This differentiated purpose of environmental education implies, consequently, a pedagogical redesigning of the professional action of present-day educators, as a scientifically based and ethically positioned commitment related to cooperative and fraternal socio-environmental citizenship. The institutional feasibility of this change, however, necessarily involves a transformation in universities in terms of their political and administrative management and their philosophical and anthropological bases—beyond technological and market bounds (Silva, 2007).

Although the research subjects are in the final year of the Bachelor of Arts (B.A.) in Geography courses, understandings as to environment and environmental education are more directed towards the relation between aspects and facts, and less towards knowledge of the underlying determinants that explain facts and that are related to the dynamic movement of knowledge and to critical (referenced) understanding of reality. This situation indicates significant differences between receiving information and integrating it into a system of knowledge.

Teacher training, through B.A. in Geography courses, should be more concerned with the need for this integration, encouraging reflection about the knowledge construction process, beyond non-contextualized isolated aspects, facts, and contents. With regard to the training of Geography undergraduates in environmental education, the curriculum needs to have a perspective that values interdisciplinarity and educational practice, as a problematization of geographical spatiality in socio-environment interrelations.

\section{References}

Bretones, P. S., \& Compiani, M. (2011). Evolução conceitual de professores sobre o movimento diário da esfera celeste (Conceptual evoluation of teachers regarding the daily movement of the celestial sphere). Ciência \& Educação, 17(3), 735-755.

Camargo, L. H. R. (2005). A ruptura do meio ambiente: Conhecendo as mudanças ambientais do planeta através de uma nova percepção da ciência-A geografia da complexidade (The environmental rupture: Getting to know the planet's environmental changes through a new scientific perception-Geography of complexity). Rio de Janeiro: Bertrand Brasil.

Campos, M. M. F. (2000). Educação ambiental e paradigmas de interpretação da realidade: Tendências reveladas (Environmental education and paradigms of interpreting reality: Tendencies revealed) (Ph.D. dissertation, The University of Campinas).

Carvalho, I. C. M. (2004). Educação ambiental: A formação do sujeito ecológico (Environmental education: Forming the ecological subject). São Paulo: Cortez.

Castellar, S. M. V. (2005). Educação geográfica: A psicogenética e o conhecimento escolar (Geographical education: Psychogenetics and school knowledge). Cadernos Cedes, 25(66), 209-225.

Cordero, S., \& Svarzman, J. (2007). Hacer geografía en la escuela: Reflexiones y aportes para el trabajo en el aula (Doing geography at school: Reflections and contributions for classroom work). Buenos Aires: Ediciones Novedades Educativas.

Damiani, A. L. A. (2001). A geografia e a construção da cidadania (Geography and the construction of citizenship). In A. F. A. Carlos (Org.), A geografia na sala de aula (Geography in the classroom) (pp. 50-61). São Paulo: Contexto. 
Delval, J. (2002). Introdução à prática do método clínico: Descobrindo o pensamento das crianças (Introduction to clinical method practice: Discovering the reasoning of children). Porto Alegre: Artmed.

Federative Rupublic of Brazil. (1999, April 27). Dispõe sobre a educação ambiental, institui a política nacional de educação ambiental e dá outras providências (Provides for environmental education, establishing the national environmental education policy and other measures). Official Gazette of the Federative Rupublic of Brazil, No. 79.

Federative Rupublic of Brazil. (2002, June 25). Decree No. 4281, Regulates Law No. 9795. Official Gazette of the Federative Rupublic of Brazil, No. 121.

Freire, A. M. A. (2007). O legado de Paulo Freire à educação ambiental (The legacy of Paulo Freire in environmental education). In F. O. Noal, \& V. H. L. Barcelos (Orgs.), Educação ambiental e cidadania: Cenários brasileiros (Environmental education and citizenship: Brazilian scenarios). Santa Cruz do Sul: Edunisc.

Freire, P. (2005). Educação e mudança (Education and change) (28th ed.). Rio de Janeiro: Paz e Terra.

Gadotti, M. (2000). Pedagogia da terra (Pedagogy of the land) (2nd ed.). São Paulo: Petrópolis.

Grün, M. (1996). Ética e educação ambiental: A conexão necessária (Ethics and environmental education: The necessary connection). Campinas: Papirus.

Guimarães, S. S. M., \& Inforsato, E. C. (2012). A percepção do professor de Biologia e sua formação: A educação ambiental em questão (Biology teachers' perceptions and training: Environmental education in question). Ciência \& Educação, 18(3), 737-754.

Leff, E. (2001). Epistemologia ambiental (Environmental epistemiology). (Sandra Valenzuela Trans.). São Paulo: Cortez.

Lima, A. M., \& Oliveira, H. T. (2011). A (re)construção dos conceitos de natureza, meio ambiente e educação ambiental por professores de duas escolas públicas (The (re)building of the concepts of nature, enviroment and education by teachers at two state schools). Ciência \& Educação, 17(2), 321-337.

Loureiro, C. F. B. (2006). Problematizando conceitos: Contribuição à práxis em educação ambiental (Problematizing concepts: Contribution to environmental education praxis). In C. F. B. Loureiro, P. P. Layrargues, \& R. S. Castro (Orgs.), Pensamento complexo, dialética e educação ambiental (Complex reasoning, dialectics and environmental education) (pp. 104-161). São Paulo: Cortez.

Lüdke, M., \& André, M. E. D. A. (1986). Pesquisa em educação: Abordagens qualitativas (Education research: Qualitative approaches). São Paulo: EPU.

Ministry of Education. (2012, June 15). Resolução n. 2: Dispõe sobre as diretrizes curriculares nacionais para a educação ambiental (Resolution No. 2: Making provisions for the national curricular guidelines for environmental education). Official Gazette of the Federative Rupublic of Brazil, Section 1, p. 18.

Nogueira, V. (2009). Educação geográfica e formação da consciência espacial-cidadã no ensino fundamental: Sujeitos, saberes e práticas (Geography education and raising spatial-civic consciousness in elementary education: Subjects, knowledge and practices) (Ph.D. dissertation, Universidade Federal do Paraná).

Piaget, J. (1926). A representação do mundo na criança (The child’s conception of the world). Rio de Janeiro: Record.

Piaget, J. (1974a). La prise de conscience (The grasp of consciousness). Paris: PUF.

Piaget, J. (1974b). Réussir et comprendre (Success and understanding). Paris: PUF.

Piaget, J. (1975). L'équilibration des structures cognitives: Problème central du développement (Equilibration of cognitive structures: The central problem of intellectual development). Paris: PUF.

Piaget, J. (1981). Le possible et le nécessaire: L'évolution des possibles chez l'enfant (Possibility and necessity: The evolution of possibilities in children). Paris: PUF.

Piaget, J. (1983). Le possible et le nécessaire: L'évolution du nécessaire chez l'enfant (Possibility and necessity: The evolution of possibilities in children). Paris: PUF.

Piaget, J. (1987). Vers une logique des significations (Toward a logic of meanings). Genève: Murionde.

Piaget, J., \& Inhelder, B. (2003). A psicologia da criança (The psychology of the child). Rio de Janeiro: Difel.

Piske, F. H. R., \& Stoltz, T. (2012). O desenvolvimento afetivo de alunos superdotados: Uma contribuição a partir de Piaget (Affective development of gifted students: A contribution based on Piaget). Schème: Revista Eletrônica de Psicologia e Epistemologia Genéticas, 4, 149-166.

Reigota, M. (1995). Meio ambiente e representação social (Environment and social representation). São Paulo: Cortez.

Ribeiro, M. W. (2006). Os conteúdos ambientais em livros didáticos de geografia de $1^{\circ}$ e $2^{\circ}$ ciclos no ensino fundamental (Environmental contents in geography textbooks in the 1st and 2nd cycles of elementary education) (M.Ed. thesis, Universidade Federal do Paraná). 
Sansolo, D. G., \& Cavalheiro, F. (2001/2003). Geografia e educação ambiental (Geography and environmental education). In J. E. Santos, \& M. Sato (Eds.), A contribuição da educação ambiental à esperança de pandora (The contribution of environmental education to Pandora’s hope) (2nd ed., pp. 109-131). São Carlos: RiMa.

Santos, J. E., \& Sato, M. (2001/2003). Universidade e ambientalismo-Encontros não são despedidas (University and environmentalism-Encounters are not farewells). In J. E. Santos, \& M. Sato (Eds.), A contribuição da educação ambiental à esperança de pandora (Environmental education: Bases, practices, and challenges) (2nd ed., pp. 31-49). São Carlos: RiMa.

Silva, A. D. V. D. (2007). Sustentabilidade no ensino superior: A emergência de uma universidade ambientalmente responsável (Sustainability in higher education: The emergence of an environmentally responsible university). In A. F. S. Guerra, \& J. E. Taglieber (Orgs.), Educação ambiental: Fundamentos, práticas e desafios (Environmental education: Bases, practices, and challenges) (pp. 143-162). Itajaí: Universidade do Vale do Itajaí.

Smith, L. (2012, October 17-18). Piaget's méthode critique and developmental epistemics. Colloque: Psychologies de l'enfant et du développement: Innovation impacts, influences. UniMail: FPSE, Université de Genève.

Stoltz, T., Costa, R. R. S., Pieczarka, T., Othman, Z. A. S., Cooper, I., \& D’Aroz, M. S. (2014). A construção de conceitos econômicos em adolescentes trabalhadores de rua do Brasil (The construction of economic concepts in adolescent street workers from Brazil). Revista Eletrônica Científica Inovação e Tecnologia, 1(9), 1-15. Retrieved January 31, 2015, from http://revista.md.utfpr.edu.br/ojs/index.php/IT/issue/view/17

Tozoni-Reis, M. F. C. (2002). Formação dos educadores ambientais e paradigmas em transição (Environmental educator training and paradigms in transition). Ciência \& Educação, 8(1), 83-96.

Vesentini, J. W. (2005). O ensino de geografia no século XXI (Geography teaching in the 21st century) (2nd ed.). Campinas: Papirus. 